\title{
Hambatan Perempuan dalam Berpartisipasi terhadap Pembangunan Nagari
}

\author{
Atika Rati, Fatmariza \\ Prodi Pendidikan Pancasila dan Kewarganegaraan \\ FIS Universitas Negeri Padang \\ E-mail: atikarati179@mail.com
}

\section{ABSTRAK}

Partisipasi perempuan dalam pembangunan masih terbatas disebabkan oleh faktor internal dan eksternal. Partisipasi perempuan dalam pembangunan Nagari secara faktual sudah mulai tampak di Kenagarian Koto Nan Duo IV Koto Hilie, Batang Kapas, Pesisir Selatan. Hal ini terlihat dalam keterlibatan perempuan dalam pembangunan di bidang infrastruktur jalan dan jembatan, meskipun partisipasnya belum berjalan optimal. Artikel ini bertujuan untuk menganalisis partisipasi perempuan dalam pembangunan. Jenis penelitian ini adalah penelitian kualitatif dengan menggunakan pendekatan etnografis. Informan penelitian terdiri atas 16 orang yang dipilih dengan purposive sampling diantaranya wali nagari, sekretaris nagari, Sekretaris Badan Permusyawaratan Nagari (BAMUS), kepala kampung, tokoh adat, tokoh agama, tokoh pendidikan, lima orang perempuan, serta empat orang masyarakat. Teknik pengumpulan data berupa observasi, wawancara, dan studi dokumentasi. Uji keabsahan data menggunakan teknik triangulasi sumber dan metode. Selanjutnya, teknik analisis data dilakukan melalui tiga alur kegiatan yaitu; reduksi data, menyajikan data, dan menarik kesimpulan atau verifikasi. Hasil penelitian menunjukkan bahwa partisipasi perempuan dalam pembangunan Nagari belum optimal disebabkan karena tingkat pendidikan, kesadaran, keterampilan dan keterbatasan waktu.

Kata Kunci: partisipasi perempuan, pembangunan Nagari, Pesisir Selatan

\section{ABSTRACT}

Women's participation in development is still limited due to internal and external factors. The participation of women in Nagari development has in fact started to appear in Kenagarian Koto Nan Duo IV Koto Hilie, Batang Kapas, Pesisir Selatan. This can be seen in the involvement of women in the development of road and bridge infrastructure, even though their participation has not been optimal. This article aims to analyze women's participation in development. This type of research is a qualitative study using an ethnographic approach. The research informants consisted of 16 people who were selected by purposive sampling including the nagari guardian, the secretary of the village, the secretary of the Nagari Consultative Body (BAMUS), village heads, traditional leaders, religious leaders, educational leaders, five women, and four community members. The data collection techniques were observation, interview, and documentation study. Test the validity of the data using the 
396 | hambaan perempuan..

triangulation technique of sources and methods. Furthermore, the data analysis technique was carried out through three activity streams, namely; data reduction, presenting data, and drawing conclusions or verification. The results showed that women's participation in Nagari development was not optimal due to the level of education, awareness, skills and time constraints.

Keywords: Woman participation, village development, Pesisir Selatan

(c) (i) (?) This work is licensed under the Creative Commons Attribution-ShareAlike 4.0 International License. BY 24 author. 


\section{PENDAHULUAN}

Keberhasilan pembangunan dalam Nagari ditandai dengan adanya keseimbangan peranan antara pemerintah dan masyarakat. Pemerintah Nagari berperan sebagai fasilitator, sedangkan masyarakat Nagari berperan sebagai pelaku atau objek utama pembangunan yang dapat dilihat dari keterlibatannya dalam hal mental, fikiran, tenaga, serta moral sehingga terciptalah tanggung jawab sosial. Partisipasi adalah keikutsertaan masyarakat sebagai bentuk perwujudan hak dan kewajiban serta peranannya dalam subjek dan objek pembangunan (Kalesaran, 2015). Partisipasi dengan pelibatan masyarakat dalam pemilihan kebijakan pembangunan didasarkan pada nilai-nilai yang tumbuh dan berkembang dalam kehidupan masyarakat (Hasba \& Syahrul, 2018).

Dapat disimpulkan bahwa partisipasi merupakan keterlibatan masyarakat dalam proses penyusunan kebijakan yang ada, contohnya dalam proses pelaksanaan pembangunan. Tingginya tingkat partisipasi masyarakat dalam pembangunan akan memberikan pengaruh pada tingkat keberhasilan pembangunan tersebut, karena salah satu tujuan dari pembangunan ialah untuk kesejahteraan masyarakat (Maripah, 2017). Keterlibatan masyarakat dalam pembangunan tidak membedakan antara laki-laki mapun kaum perempuan, laki-laki maupun perempuan memiliki kesempatan dan tempat yang sama dalam pembangunan. Hal ini sesuai dengan amanah pembukaan UUD 1945 pasal 28D ayat 3 yang berbunyi "setiap warga Negara berhak memperoleh kesempatan yang sama dalam pemerintahan".

Partisipasi masyarakat dalam kajian ini difokuskan pada partisipasi perempuan dalam pembangunan Nagari, karena partisipasi perempuan menjadi syarat mutlak dalam upaya mewujudkan pembangunan Nagari yang berkeadilan. Partisipasi perempuan diartikan dengan keterlibatan perempuan dalam bermasyarakat, perempuan memiliki peranan dalam hubungan sosial kemasyarakatan, serta memiliki tempat tersendiri sebagai anggota masyarakat. Peranan perempuan dalam pembangunan Nagari dapat mengangkat harkat serta kualitas dari perempuan itu sendiri. Peranan perempuan dalam pembangunan dapat dilihat khususnya dalam pemberdayaan sosial, ekonomi, pendidikan, kesehatan serta pemberdayaan peningkatan sarana prasarana (Rinawati, 2004). Bentuk partisipasi perempuan lainnya misalnya terdapat dalam kepanitiaan Musyawarah Perencanaan Pembangunan Kelurahan (Musrenbangkel). Mereka menyampaikan usulan dalam sidang komisi, serta menjadi perwakilan utusan kelurahan (Ekawati, 2010). 
Di Sumatera Barat sendiri, terdapat lembaga Bundo Kanduang yang ada di Nagari sebagai kekuatan dalam pembangunan pemberdayaan perempuan, namun lembaga ini belum mampu sepenuhnya untuk meningkatkan keterlibatan perempuan di Nagari (Yunarti, 2017). Sehingga, partisipasi perempuan dalam pembangunan kondisinya masih belum optimal, karena lebih memfokuskan pada pendekatan pemberdayaan sosial, sarana prasarana dan pemberdayaan lembaga Bundo Kanduang.

Dalam penelitian ini penulis memfokuskan pada partisipasi perempuan dalam pelaksanaan pembangunan Nagari di Kenagarian Koto Nan Duo IV Koto Hilie, Kabupaten Pesisir Selatan, khususnya di bidang infrastruktur. Penulis ingin melihat bagaimana keterlibatan perempuan dalam pelaksanaan pembangunan Nagari, serta faktor apa saja yang mempengaruhi rendahnya partisipasi perempuan dalam pelaksanaan pembangunan di Nagari.

Kondisi awal menunjukkan kurangnya partisipasi perempuan dalam pembangunan Nagari dan lebih menyerahkan pelaksanaan pembangunan kepada pihak lakilaki, yang dapat dilihat dari rendahnya kesadaran kaum perempuan untuk terlibat dalam pembangunan jalan dan jembatan wisata Nagari, masih rendahnya jiwa kegotong royongan perempuan untuk ikut serta dalam pelaksanaan pembangunan jalan nagari. Hal ini sejalan dengan data dari Biro Pemberdayaan Perempuan Pemerintah Daerah Sumatera Barat yang menunjukkan bahwa perempuan belum banyak ikut serta dalam pemerintahan Nagari. Walaupun pada sebagian perempuan yang telah berpendidikan mulai berpartisipasi dalam berbagai organisasi dan ikut dalam pembangunan Nagari, tetapi masih relatif kecil bila dibanding dengan jumlah perempuan (Faridah, 2012).

Adapun salah satu penyebab dari rendahnya partisipasi perempuan dalam pelaksanaan pembangunan Nagari disebabkan oleh tingkat pendidikan, pekerjaan, kesehatan, dan faktor lainnya. Rendahnya pendidikan perempuan yang berakibat pada rendahnya Sumber Daya Manusia perempuan yang dihasilkan, dengan latarbelakang pendidikan yang rendah sehingga pekerjaan perempuanpun hanya berada pada bidang buruh, dengan pekerjaan tersebut maka tuntutan kesehatan seringkali dipandang sebelah mata oleh kaum perempuan.

\section{METODE PENELITIAN}

Jenis penelitian ini termasuk pada penelitian kualitatif dengan menggunakan metode etnografis. Metode kualitatif etnografis lebih menekankan pada budaya kelompok 
sosial dimana peneliti mempelajari pola perilaku, kebiasaan, dan cara hidup dari kelompok sosial tersebut, sehingga dapat menghasilkan makna dari objek secara alamiah, meliputi tempat, pelaku dan aktivitas (Sugiyono, 2017). Dalam penetapan informan penulis menggunakan teknik purposive sampling, yaitu penentuan informan dengan pertimbangan tertentu yang disesuaikan dengan objek yang akan diteliti oleh sipeneliti (Sugiyono, 2017). Adapun informan penelitian ini diantaranya ialah wali nagari, sekretaris nagari, sekretaris Badan Permusyawaratan (BAMUS) Nagari, kepala kampung, tokoh adat, tokoh agama, tokoh pendidikan, perempuan serta masyarakat setempat.

Pengumpulan data dilakukan dengan menggunakan observasi terhadap partisipasi perempuan dalam pelaksanaan pembangunan pada bidang infrastruktur Nagari. Teknik pengumpulan data diperkuat dengan kegiatan wawancara dan studi dokumentasi. Uji keabsahan data dilakukan dengan teknik triangulasi. Teknik triangulasi yang digunakan ialah teknik triangulasi sumber dan triangulasi metode. Triangulasi sumber yaitu membandingkan dan mengecek balik derajat kepercayaan suatu informasi yang diperoleh melalui sumbersumber yang berbeda, sedangkan triangulasi metode diartikan dengan pengecekan terhadap penggunaan metode pengumpulan data yang digunakan, sehingga penulis mampu menjelaskan perbedaan untuk mendapatkan kesamaan data yang diperoleh. Sementara itu, data dianalisis dengan teknik reduksi data, penyajian data, dan penarikan kesimpulan.

\section{HASIL DAN PEMBAHASAN}

Keterlibatan perempuan dalam pembangunan Nagari memberikan pengaruh besar terhadap jalan dan suksesnya pembangunan (Rinawati, 2007). Perempuan seharusnya memiliki tempat di setiap kegiatan pembangunan yang dapat mengatasi kesenjangan pembangunan. Ukuran partisipasi perempuan dalam pembangunan dapat dilihat dari beberapa aspek berikut; perempuan merupakan pelaku/pelaksana pembangunan, perempuan terlibat langsung terhadap pengendalian dari pelaksanaan kegiatan pembangunan, pengambil keputusan, penasehat dalam proses pembangunan, serta perempuan juga berperan sebagai penerima manfaat dalam pembangunan. Hasil pembangunan juga harus bisa dinikmati oleh perempuan, hal ini memberi indikasi bahwa pembangunan yang direncanakan sudah mempertimbangkan perempuan sebagai penerima manfaat pembangunan.

Namun, berdasarkan data yang didapatkan di lapangan belum 
menunjukkan partisipasi aktif perempuan dalam kegiatan pembangunan yang dilaksanakan. Hal ini dipengaruhi oleh faktor ekonomi, struktur umur, pendidikan, kelas sosial, serta tingkat kesehatan perempuan. Dalam penelitian ini penulis memfokuskan pada partisipasi perempuan dalam pelaksanaan pembangunan di bidang infrastruktur khususnya pada bagian pembangunan jalan pemukiman dan jembatan wisata Sungai Tawa di Kenagarian Koto Nan Duo IV Koto Hilie, Kabupaten Pesisir Selatan.

Bidang Infrastruktur dan Lingkungan Nagari

Partisipasi perempuan dalam pembangunan di bidang infrastruktur Nagari dapat dilihat melalui keterlibatannya dalam bidang pembangunan jalan pemukiman, dan jembatan wisata Sungai Tawa. Salah satu tujuan pembangunan jalan adalah memperlancar lalu lintas di daerah, meningkatkan pemerataan hasil pembangunan dan keadilan. Berdasarkan pengamatan dan hasil wawancara penulis dengan bapak Ben Suhardi SH selaku wali nagari di Kenagarian Koto Nan Duo IV Koto Hilie, beliau mengatakan bahwa dalam proses pelaksanaan pembangunan jalan aspal hotmix Sungai Bungin Tampuniak, partisipasi perempuan dilihat dari keterlibatannya untuk ikut bekerja membersihkan sekitaran jalan yang akan dibangun, berkontribusi dalam memberikan sarapan dan makanan kepada pekerja secara bergiliran. Ikut serta meminjamkan barang maupun alat yang digunakan dalam pembangunan jalan dan jembatan wisata tersebut.

Tidak hanya itu saja, dalam pembangunan jembatan wisata Sungai Tawa, perempuan juga ikut terlibat untuk mempromosikan serta memperkenalkan wisata yang ada di Sungai Tawa. Promosi mereka lakukan melalui akun media sosial seperti Facebook, Whatsapp, Instagram, Twitter. Adapaun promosinya menyangkut objek wisata bahari yang ada, keunggulan objek wisata di Kenagarian Koto Nan Duo IV Koto Hilie. Akan tetapi kenyataan yang ditemui dilapangan, masih banyaknya perempuan yang belum terlibat aktif untuk membantu dan mendorong jalannya pembangunan jalan dan jembatan wisata tersebut, kaum perempuan dominan masih terkendala dalam pembagian waktu antara tugas dibidang domestik dan tugasnya dibidang publik, bahkan sebagiannya lebih memilih untuk berperan di bidang domestik saja. Rendahnya partisipasi perempuan dalam kegiatan pembangunan jalan pemukiman serta pembangunan jembatan wisata dapat dilihat dari tabel di bawah ini : 
Tabel 1

Partisipasi Masyarakat dalam Pembangunan Jalan Pemukiman dan Jembatan Wisata Tahun 2019

\begin{tabular}{|c|c|c|c|}
\hline No & Nama Masyarakat & $\begin{array}{c}\text { Jenis } \\
\text { Kelamin }\end{array}$ & Pekerjaan \\
\hline 1. & Muhammad Haris & $\mathrm{L}$ & Pegawai \\
\hline 2. & Trisna Nelda Yeni & $\mathrm{P}$ & Ibu Rumah tangga \\
\hline 3. & Sukril & $\mathrm{L}$ & Petani \\
\hline 4. & Darwin Zen & $\mathrm{L}$ & Petani \\
\hline 5. & Anton Syahda & $\mathrm{L}$ & Nelayan \\
\hline 6. & Syafri Wandri Fauzi & $\mathrm{L}$ & Kepala kampung \\
\hline 7. & Novri Wahyudi & $\mathrm{L}$ & Wiraswasta \\
\hline 8. & Iris & $P$ & Buruh tani \\
\hline 9. & Hendriyani & $\mathrm{L}$ & Nelayan \\
\hline 10. & Erlena & $P$ & Ibu rumah tangga \\
\hline 11. & Arisman & $\mathrm{L}$ & Buruh tani \\
\hline 12. & Megi Pratama & $\mathrm{L}$ & Petani \\
\hline 13. & Didi Mulyadi & $\mathrm{L}$ & Nelayan \\
\hline 14. & Yepi Anggia & $P$ & Buruh tani \\
\hline 15. & Eva Susanti & $\mathrm{P}$ & Buruh tani \\
\hline 16. & Yusnofatriani & $P$ & Pedagang \\
\hline 17. & Epis Suwadi & $\mathrm{L}$ & Petani \\
\hline 18. & Lisa Pringka Genita & $P$ & Istri nelayan \\
\hline
\end{tabular}

Sumber : Dokumentasi Penulis Tahun 2019

Terkait dengan tabel diatas, diperoleh gambaran bahwa partisipasi perempuan pada bidang infrastruktur seperti pembangunan jalan dan jembatan wisata Sungai Tawa belum mewakili jumlah kaum perempuan yang ada di Kenagarian Koto Nan Duo IV Koto Hilie. Hal ini terlihat dari jumlah perempuan yang ikut dalam kegiatan pembangunan jalan dan jembatan wisata tersebut, hanya tujuh orang perempuan yang terlibat dalam kegiatan pembangunan. Sedangkan sebelas orang lainnya ialah kaum laki-laki. Dari tabel diatas dapat ditarik kesimpulan bahwa masih belum optimalnya keterlibatan perempuan dalam pelaksanaan pembangunan.

Data diatas juga diperkuat dengan hasil wawancara yang penulis lakukan dilapangan, dengan mewawancarai ibu Trisna selaku ibu rumah tangga beliau mengatakan bahwa keterlibatan kaum perempuan dalam pembangunan jalan dan jembatan wisata memang tidak seperti lakilaki, karena keterbatasan waktu yang dimiliki oleh perempuan, tapi perempuan ikut berkontribusi menyumbangkan materi seperti uang, dan ikut goro bersama membersihkan badan jalan. Belum optimalnya partisipasi perempuan dalam pembangunan Nagari juga dapat dilihat dari keikutsertaan perempuan dalam struktur pelaksana kegiatan pembangunan jalan Subarang Gunung Gadang dan jembatan wisata Sungai Tawa Tahun 2019. 
Tabel 2

\section{Struktur Pelaksana Kegiatan \\ Pembangunan Tahun 2019}

\begin{tabular}{|l|l|l|}
\hline No & Nama & Jabatan \\
\hline 1. & Muhammad Haris & Penanggung Jawab \\
\hline 2. & Trisna Nefda Yeni & Ketua \\
\hline 3. & Sukril & Anggota \\
\hline 4. & Darwin Zen & Anggota \\
\hline 5. & Anton Syahda & Anggota \\
\hline 6. & Syafri Wandri Fauzi & Anggota \\
\hline 7. & Novri Wahyudi & Anggota \\
\hline 8. & Iris & Masyarakat \\
\hline 9. & Hendriyani & Masyarakat \\
\hline 10. & Erlena & Masyarakat \\
\hline 11. & Arisman & Pekerja \\
\hline 12. & Megi Pratama & \\
\hline
\end{tabular}

Sumber : Kantor Wali Nagari tahun 2020

Terkait dengan tabel diatas, diperoleh gambaran bahwa dari 12 anggota pelaksana kegiatan pembangunan jalan dan jembatan tahun 2019, hanya empat orang perempuan yang ikut terlibat dalam keanggotaan struktur pelaksana kegiatan pembangunan jalan dan jembatan wisata tersebut, sedangkan sembilan orang lainnya ialah kaum laki-laki, hal ini membuktikan bahwa masih belum optimalnya partisipasi perempuan dalam pelaksanaan pembangunan Nagari.

Gambaran umum tentang partisipasi perempuan dalam pembangunan di bidang infrastruktur khususnya pembangunan jalan dan jembatan wisata Sungai Tawa belum mewakili jumlah kaum perempuan yang ada di Nagari. Salah satu penyebab rendahnya partisipasi perempuan dalam pembangunan nagari tersebut adalah beban ganda yang dihadapi oleh kaum perempuan. Selain berperan di bidang domestik perempuan juga berperan di bidang publik, perempuan harus membagi waktunya di antara kedua peran tersebut. Beban ganda juga diperburuk dengan latar belakang pendidikan perempuan yang rendah, sehingga mempengaruhi kualitas relasi hubungan perempuan dengan orang lain.

Faktor yang Mempengaruhi Partisipasi Perempuan dalam Pembangunan Nagari

Rinawati,

mengemukakan

rendahnya partisipasi perempuan dalam pembangunan, disebabkan oleh beberapa kendala berikut ini :

1. Wanita secara psikologis terbiasa dengan kondisi sebagai bagian masyarakat yang terpinggirkan, sehingga kesadaran untuk turut serta dalam proses pembangunan menjadi tidak maksimal. 
2. Adanya kebiasaan "dicekoki" sebagai warisan dari konsep pembangunan yang top down, sehingga wanita belum siap bertindak sebagai subjek yang menentukan arah pembangunan.

3. Masih banyaknya wanita yang tidak berani untuk tampil ke depan dan mengemukakan pikiran atau ideidenya, sehingga mereka seringkali hanya meng"ya"kan perencanaan dan pelaksanaan yang dikemukakan oleh para pria.

Berdasarkan temuan penulis dilapangan dapat disimpulkan bahwa tinggi atau rendahnya partisipasi perempuan dalam pelaksanaan pembangunan Nagari, dipengaruhi oleh beberapa hal berikut: pertama, sektor pendidikan dimana pendidikan perempuan di Kenagarian Koto Nan Duo IV Koto Hilie masih tergolong rendah. Jumlah perempuan yang tamatan SD sebanyak 692 orang, SMP/Sederajat 400 orang, SMA/Sederajat 645 orang, Diploma 24 orang, Sarjana 40 orang, sebagian kecil masih adanya perempuan yang putus sekolah yang tidak mampu melanjutkan pendidikan ke jenjang yang lebih tinggi.

Rendahnya pendidikan perempuan disebabkan oleh kurangnya kesadaran masyarakat dan orang tua akan pentingnya pendidikan bagi perempuan. Adanya budaya yang menganggap bahwa perempuan itu lebih cocok bekerja di ranah domestik dengan menjadi ibu rumah tangga dibandingkan di ranah publik. Dari hal diatas, dapat ditarik kesimpulan bahwa tingkat pendidikan mempengaruhi pengetahuan seseorang, dimana, semakin tinggi latarbelakang pendidikan perempuan maka semakin tinggi pula pemahaman, wawasan, skill, dan pengetahuannya, begitupun pengalaman yang dihasilkan.

Kedua, rendahnya tingkat pendapatan yang dihasilkan oleh perempuan mempengaruhi kesejahteraan kehidupannya. Semakin rendah produktivitas perempuan maka semakin rendah pula simpanan dan investasi perempuan (Sari, 2016). Dampak yang ditimbulkan adalah terbelakangnya perempuan dalam pembangunan. Perempuan di Nagari Koto Nan Duo IV Koto Hilie dominan bekerja sebagai buruh tani, buruh harian lepas, pedagang kecil dan sektor kecil lainnya, sehingga taraf kesejahteraan perempuan di sana masih tergolong ke dalam taraf ekonomi menengah kebawah.

Tingkat pendapatan yang dihasilkan oleh perempuan baik sebagai buruh tani,buruh harian lepas, petani, pedagang, maupun wiraswasta sangatlah rendah. Ratarata perempuan tersebut berpenghasilan satu juta rupiah/bulan mereka berjumlah 210 perempuan. Sedangkan perempuan yang berpendapatan besar dari dua 
juta rupiah/bulan sebanyak 125 orang.

Ketiga Terbatasnya Lapangan Pekerjaan di Nagari. Lapangan pekerjaan di Nagari Koto Nan Duo IV Koto Hilie diantaranya ialah bertani, kesawah, berkebun dan nelayan. Terbatasnya lapangan pekerjaan di Nagari dapat menyebabkan kemiskinan penduduk, yang berakibat pada meningkatnya jumlah masyarakat miskin di Nagari. Dampak yang ditimbulkan dari terbatasnya lapangan pekerjaan di Nagari dapat menyebabkan penghasilan masyarakat rendah, meningkatknya jumlah penduduk miskin, tingkat pengangguran, kurangnya kreativitas perempuan, serta rendahnya tingkat kesejahteraan perempuan (Sari, 2016)

\section{KESIMPULAN}

Berdasarkan uraian hasil penelitian yang telah penulis kemukakan tentang partisipasi perempuan dalam pembangunan Nagari di Kenagarian Koto Nan Duo IV Koto Hilie dapat disimpulkan bahwa partisipasi perempuan dalam pembangunan Nagari di Kenagarian Koto Nan Duo IV Koto Hilie terdiri atas partisipasi aktif/langsung serta partisipasi pasif/tidak langsung. Partisipasi aktif/langsung terlihat dari keaktifan perempuan dalam mengikuti kegiatan pembangunan yang dilaksanakan pada bidang infrastruktur khususnya pada pembangunan jalan pemukiman dan jembatan wisata Sungai Tawa, sedangkan partisipasi pasif/tidak langsung terlihat dari keaktifan ibuibu mendidik anaknya, mengontrol belajar anaknya dirumah dalam hal penggunaan gadget, menanamkan dasar-dasar nilai keagamaan, mengajarkan akhlak atau perilaku moral, memberikan asupan makanan yang mengandung empat sehat lima sempurna, dan lain sebagainya.

Dalam pelaksanaannya, partisipasi perempuan dalam pembangunan Nagari sudah terlaksana, namun partisipasi perempuan belum berjalan optimal. Hal ini terlihat dari rendahnya keterlibatan perempuan untuk mengikuti kegiatan pembangunan jalan dan jembatan wisata Sungai Tawa. Penyebab lainnya juga dilatarbelakangi oleh tingkat pendidikan perempuan, dan program Nagari yang lebih memfokuskan pada pembangunan dibidang fisik dan prasarana, sehingga partisipasi perempuan kurang tersalurkan. Hal tersebut dapat diakibatkan dari beban ganda yang ditanggung oleh perempuan yang harus bekerja di ranah domestik juga berperan di ranah publik.

Adapun faktor-faktor lain yang mempengaruhi partisipasi perempuan dalam pembangunan Nagari di Kenagarian Koto Nan Duo IV Koto Hilie yang penulis temukan dilapangan antara lain ialah keterbatasan waktu, tingkat pendidikan perempuan yang masih 
kebanyakan tamatan SMA/Sederajat, rendahnya pendidikan perempuan disebabkan oleh minimnya biaya untuk melanjutkan pendidikan, serta adanya anggapan dari orangtua dan masyarakat bahwa perempuan lebih cocok bekerja dibidang domestik atau mengurus Rumah Tangga.

Rendahnya partisipasi perempuan dalam pembangunan Nagari juga disebabkan oleh rendahnya tingkat pendapatan perempuan, karena perempuan dominan bekerja di sektor pertanian, sehingga pendapatan yang dihasilkan belum mampu mencukupi kebutuhan hidupnya, yang juga memberikan pengaruh pada tingkat kesadaran perempuan, terkikisnya nilai-nilai gotong royong. Belum optimalnya fungsi lembaga yang bergerak dibidang pertanian seperti Gabungan Kelompok Tani (GAPOKTAN), Kelompok Wanita Tani (KWT), banyaknya masyarakat yang berada pada tingkatan ekonomi menengah kebawah, serta keterbatasan sumber daya manusia.

\section{DAFTAR PUSTAKA}

Ekawati, Sri. 2010. "Partisipasi Perempuan dalam Musyawarah Perencanaan

Pembangunan".Surakarta : Jurusan Sosiologi Universitas Sebelas Maret.

Faridah. 2012. "Keterlibatan Perempuan Dalam Bermasyarakat : Studi Pada Masyarakat Pantai
Kabupaten Padang Pariaman." Jurnal Humonus Volume XI Nomor 1.

Hasba, Sandra \& Syahrul. 2018. "Partisipasi Masyarakat dalam Pembangunan : Kasus Kelurahan Bungguosu, Konawe". Jurnal Shautut Tarbiyah. Volume 38. Nomor XXIV.

Kalesaran, Ferdinand. 2015. "Partisipasi dalam Program Nasional Pemberdayaan Masyarakat Mandiri Perkotaan Kelurahan Taas Kota Manado."Jurnal Acta Diurna.Volume IV Nomor 5.

Maripah. 2017. "Perencanaan Pembangunan Partisipatif dalam Penyusunan Rencana Pembangunan Jangka Menengah Desa (RPJMDES) di Desa Pangkalan Baru Kecamatan Siak Hulu Kabupaten Kampar". Jurnal Fisip. Volume 4 Nomor 2.

Rinawati, Rini. 2004. "Partisipasi Wanita dalam Pembangunan". Jurnal An'atanal Volume 20 NOMOR 3. Hal 387- 405.

Rinawati, Rini. Dkk. 2007."Keterlibatan Perempuan dalam Pengambilan Keputusan Pada Perencanaan Pembangunan".Jurnal An'atanal Volume 23 Nomor 2.Hal 157177. 
406 | hambaan perempuan..

Sari, Ita Puspita. 2016. “Implementasi Pembangunan Partisipatif : Studi Kasus di Kelurahan Andowia Kabupaten Konawe Utara". Jurnal Ekonomi. Volume 1 Nomor 1.

Sugiyono.2017. .Metode Penelitian Pendidikan. Bandung : Alfabeta $\mathrm{cV}$.

Yunarti, Sri. 2017. "Pemberdayaan Lembaga Bundo Kanduang di Nagari melalui Kebijakan Pembangunan yang Responsif Gender". Jurnal Kafaah Volume 7 Nomor 2.Hal. 221234 